\title{
Perubahan Struktur Ekonomi, Dekomposisi Sumber Pertumbuhan Output, dan Pertumbuhan Total Factor Productivity (TFP): Analisis Lanjutan Tabel Input-Output Provinsi Kalimantan Selatan, 2000- 2010
}

\author{
Nurul Fajri ${ }^{1}$, Mudrajad Kuncoro ${ }^{2}$ \\ 1. Badan Pusat Statistik Kabupaten Temanggung, Indonesia \\ 2. Fakultas Ekonomika dan Bisnis, Universitas Gadjah Mada, Indonesia \\ E-mail: nurul.fajri@bps.go.id
}

Diterima: May 20, 2016; Disetujui: September 29, 2016; Dipublikasikan: November 4, 2016 Permalink/DOI: http://dx.doi.org/10.17977/um002v8i22016p217

\begin{abstract}
Economic growth can be seen from the aggregate demand side, namely consumption, investment, government spending, exports and imports, and the aggregate supply side namely labor growth, capital growth and the growth of TFP (Total Factor Productivity). This study uses South Kalimantan's Input-Output Tables of 2000, 2005 and 2010. The results showed that although the structure of the value-added of the mining sector remains the main economic pillar, but this sector has low linkages with other sectors. Based Multiplier Product Matrix, manufacturing industry suggest a leading role in the economy so that it can be said that the province of South Kalimantan are heading toward a change in the economic structure. Decomposition of sources of growth based on the Chenery's model (1960) showed that the main source of economic growth in South Kalimantan is exports by 67 percent in the period 2000-2005 and 73.72 percent in the period 2005-2010, especially the export of coal. Decomposition of productivity growth made by Namura and Kuroda's model (2004) and suggests that TFP growth and capital have a strong linear relationship and significant Output growth, while labor productivity have no significant correlation with Output growth. Finally, the wealth of the abundant natural resources, industryoriented economic growth and sustainable development in South Kalimantan Province is agriculture-based industries and mining-based industries with the main strategy is to import substitution and investment in capital and technology.
\end{abstract}

Keywords: Input-Output Tables, Multiplier Product Matrix, Decomposition of output growth, Total Factor Productivity

JEL Classification: C67, 047

\section{PENDAHULUAN}

Pertumbuhan ekonomi yang tinggi merupakan target pembangunan di setiap daerah. Provinsi Kalimantan Selatan merupakan provinsi yang memiliki pertumbuhan ekonomi yang cukup tinggi. Pada tahun 2001, pertumbuhan ekonomi Provinsi Kalimantan Selatan adalah 4,15 persen, jauh lebih tinggi dibanding Provinsi Kalimantan Tengah yaitu sebesar 2,72 persen dan lebih tinggi dari pertumbuhan 
Indonesia yaitu 3,99 persen. Setelah pembangunan berjalan selama 10 tahun, Provinsi Kalimantan Selatan hanya mencapai pertumbuhan ekonomi sebesar 5,58 persen, di bawah pertumbuhan ekonomi Provinsi Kalimantan Tengah yang mencapai 6,47 persen dan juga di bawah pertumbuhan ekonomi nasional yang mencapai 6,09 persen. Hal ini menunjukkan bahwa laju pertumbuhan ekonomi Provinsi Kalimantan Selatan tidak secepat laju pertumbuhan ekonomi Provinsi Kalimantan Tengah dan nasional, di mana rata pertumbuhan ekonomi selama 10 tahun tersebut adalah 5,08 persen untuk Provinsi Kalimantan Selatan, 5,20 persen untuk Provinsi Kalimantan Tengah dan 5,13 persen untuk nasional. Agar tidak mengalami ketertinggalan dan ketimpangan pertumbuhan ekonomi dengan daerah lain maka Provinsi Kalimantan Selatan harus meningkatkan laju pertumbuhan ekonominya. Oleh karena itu diperlukan identifikasi sektor-sektor penggerak dan pendorong utama perekonomian dan sumber-sumber pertumbuhan ekonomi sehingga perekonomian dapat tumbuh dengan lebih cepat.

Dalam jangka panjang, pembangunan ekonomi akan membawa perubahan mendasar dalam struktur ekonomi. Kuznet mendefinisikan pertumbuhan ekonomi merupakan kenaikan terus menerus dalam produk/output per kapita atau per pekerja dan biasanya diikuti dengan perubahan struktural (Jhinghan, 2003: 57). Perubahan struktur ekonomi penting karena sektor primer sangat tergantung pada sumber daya alam yang terbatas jumlahnya dan memiliki produktifitas rendah. Kuncoro (2010: 289) berpendapat bahwa industrialisasi merupakan strategi untuk meningkatkan produktifitas dan efisiensi penggunaan faktor produksi. Hal ini sejalan dengan pendapat para ekonomi dunia bahwa efisiensi alokasi sumber daya penting untuk menjaga pertumbuhan output jangka panjang.

Fakta empiris menunjukkan bahwa di Provinsi Kalimantan Selatan sektor pertanian dan pertambangan semakin menjadi primadona dalam PDRB total, yaitu sebesar 44,48 persen pada tahun 2000 terus meningkat hingga mencapai 46,19 persen pada tahun 2009 dan sedikit menurun menjadi 45,87 persen pada tahun 2010 . Sebaliknya pangsa sektor industri justru cenderung menurun, yaitu sebesar 15,99 persen pada tahun 2000 kemudian menurun hingga mencapai 10,59 persen pada tahun 2010.Kondisi ini berbeda dengan perubahan struktur ekonomi yang terjadi di Indonesia secara umumnya, di mana peran sektor pertanian dan pertambangan memiliki kecenderungan turun, sedangkan peran sektor industri pengolahan mengalami kecenderungan naik sepanjang tahun $2000-2010$.

\section{KAJIAN PUSTAKA}

Teori perubahan struktural menitikberatkan pembahasan pada mekanisme transformasi ekonomi yang dialami oleh negara-negara sedang berkembang yang semula bersifat subsisten dan menitikberatkan sektor pertanian menuju struktur perekonomian yang didominasi sektor non primer, khususnya industri. Lewis (1954) dengan teori surplus tenaga kerja dua sektor (two sector surplus labor) sebagaimana diacu Jhinghan (2003:156) membahas proses pembangunan ekonomi yang terjadi di pedesaan dan perkotaan (urban). Di pedesaan terjadi kelebihan suplai tenaga kerjaditandai dengan nilai produk marjinalnya nol dan tingkat upah riil yang rendah, sedangkan perkotaan dicirikan dengan sektor industri modern dengan tingkat produktivitas tinggi dan menjadi tempat penampungan tenaga kerja dari sektor 
subsisten di pedesaan. Teori pola pembangunan oleh Chenery dan Syrquin (1975) menyatakan bahwa pertumbuhan ekonomi yang tinggi dalam jangka waktu panjangakan menyebabkan kontribusi sektor pertanian terhadap pembentukan output dan penyerapan tenaga kerja semakin menurun, sedangkan kontribusi sektor industri pengolahan akan semakin meningkat. Kuznets dalam Chenery dan Syrquin (1975) mendefinisikan bahwa perubahan struktur ekonomi sebagai rangkaian perubahan yang saling terkait satu dengan lainnya dalam komposisi permintaan agregat, perdagangan luar negeri (ekspor dan impor), dan penawaran agregat (produksi dan penggunaan faktor-faktor produksi seperti tenaga kerja dan modal) yang diperlukan guna mendukung proses pembangunan dan pertumbuhan ekonomi yang berkelanjutan.

Pertumbuhan ekonomi diukur dengan pertumbuhan Produk Domestik Bruto (PDB) yaitu nilai barang dan jasa akhir yang diproduksi dalam suatu perekonomian selama kurun waktu tertentu. Sumber pertumbuhan PDB dapat dilihat dari dua sisi, yaitu sisi permintaan agregat dan sisi penawaran agregat. Dari sisi penawaran agregat, pertumbuhan ekonomi atau output ditentukan olehfaktor-faktor produksi yaitu modal (K) dan tenaga kerja (L)serta fungsi produksi. Secara matematis dituliskan $Y=$ $F(K, L)$. Dengan memasukkan perubahan teknologi maka persamaan pertumbuhan ekonomi adalah

$$
\frac{\Delta Y}{Y}=\alpha \frac{\Delta K}{K}+(1-\alpha) \frac{\Delta L}{L}+\frac{\Delta A}{A}
$$

$\Delta A / A$ merupakan pertumbuhan produktivitas faktor total yaitu perubahan output yang tidak dapat dijelaskan oleh perubahan input dan sering dianalogkan sebagai kemajuan teknologi. Namun faktor lain seperti pendidikan dan peraturan pemerintah juga bisa mempengaruhi produktifitas faktor total (Mankiw, 2007: 241). Peningkatan output dari sisi permintaan agregat disebabkan karena peningkatan pendapatan nasional yang terdiri atas konsumsi (C), investasi (I), pembelian pemerintah $(\mathrm{G})$, dan ekspor neto $(\mathrm{NX})$. Secara matematis dapat dituliskan sebagai berikut: $Y=C+I+G+N X$

Konsep pertumbuhan tidak berimbang dipopulerkan oleh Hirschman (1958); Jhinghan (2003) dan menjadi dasar bagi pentingnya identifikasi sektor utama dalam perekonomian. Investasi pada sektor yang strategis akan lebih banyak menghasilkan kesempatan investasi baru dan membuka jalan bagi pembangunan ekonomi lebih lanjut. Pertumbuhan akan menjalar dari satu sektor ke sektor lainnya, dari satu industri ke industri lainnya atau dari satu perusahaan ke perusahaan lainnya. Kebijakan pembangunan harus diarahkan pada sektor-sektor yang mempunyai kaitan paling luas danhanya dapat dilakukan dengan studi empiris dengan menggunakan tabel inputoutput.

\section{METODE}

\section{Sumber Data}

Data pokok yang digunakan dalam penelitian ini adalah tabel input-ouput Provinsi Kalimantan Selatan atas dasar harga podusen tahun 2000, 2005 dan 2010 dengan klasifikasi 50x50 sektor. Untuk kepentingan analisis dan ketersediaan data pendukung lainnya, maka dilakukan agregasi sektor menjadi 26x26 sektor dengan mengacu pada Klasifikasi Baku Lapangan Usaha (KBLI) tahun 2005. Data sekunder 
lain bersumber dari Badan Pusat Statistik. Untuk keterbandingan antar tahun, maka tabel input-output dideflasikan dengan PDRB deflator seperti yang digunakan oleh Hayashi (2005) dan merupakan teknik yang dianjurkan oleh Badan Pusat Statistik (2000).

\section{Metode Analisis}

Notasi dasar yang digunakan dalam penelitian ini adalah $X_{i}=$ output sektor ke $\mathrm{i}$ (vektor baris), $X_{j}=$ input sektor ke j (vektor kolom), $X_{i j}=$ input dari sektor i yang digunakan oleh sektor $\mathrm{j}$ (matriks konsumsi antara), $Y_{i}=$ output sektor i yang digunakan untuk permintaan akhir, $Z_{j}=$ input primer (nilai tambah) yang digunakan sektor j.Persamaan umum dari tabel input-output adalah: $X_{i}=\sum_{j=1}^{n} X_{i j}+Y_{i}$ dan $X_{j}=$ $\sum_{i=1}^{n} X_{i j}+Z_{j}$ sehingga $\sum_{i=1}^{n} X_{i}=\sum_{i=1}^{n} \sum_{j=1}^{n} X_{i j}+\sum_{i=1}^{n} Y_{i} \quad$ dan $\quad \sum_{j=1}^{n} X_{j}=$ $\sum_{i=1}^{n} \sum_{j=1}^{n} X_{i j}+\sum_{j=1}^{n} Z_{j}$. Dari tabel input-output dapat dihitung koefisein input yaitu $a_{i j}=\frac{X_{i j}}{X_{j}}$ sehingga $X_{i}=\sum_{j=1}^{n} a_{i j} X_{j}+Y_{i}$. Dengan menggunakan notasi matriks, maka persamaan diatas dapat dituliskan menjadi $\mathbf{X}=\mathbf{A X}+\mathbf{Y}$ atau $\mathbf{Y}=(\mathbf{I}-\mathbf{A}) \mathbf{X}$ di mana (I-A) disebut sebagai matriks Leontief atau $\mathbf{X}=(\mathbf{I}-\mathbf{A})^{\mathbf{- 1}} \mathbf{Y} \operatorname{dimana}(I-A)^{-1}$ disebut sebagai matriks kebalikan Leontief (Leontief's inverse matrix).Jika $B=$ $(I-A)^{-1}$ maka $B_{i .}=\sum_{j=1}^{n} b_{i j}$, menunjukkan bagaimana output suatu sektor digunakan sebagai input bagi sektor lain $\operatorname{dan} B_{. j}=\sum_{i=1}^{n} b_{i j}$, menujukkan seberapa besar ketergantungan input sektor tersebut dari sektor lain.

Untuk perbandingan keterkaitan antara sektor maka dibuat indeks kepekaan penyebaran (sensitivity of dispersion index) atau $F L_{i}$ dan indeks daya penyebaran (power of dispersion) atau disebut dengan indeks keterkaitan ke belakang (backward linkage index) atau $B L_{i}$ sebagai berikut:

$$
F L_{i}=\frac{B_{i .}}{n} /_{\frac{V}{n^{2}}}=\frac{B_{i .}}{V / n} B L_{i}=\frac{B_{. j}}{n} / \frac{V}{n^{2}}=\frac{B_{. j}}{V / n} \text { di mana } V=\sum_{i=1}^{n} \sum_{j=1}^{n} b_{i j}
$$

Suatu sektor disebut sebagai sektor kunci (key sector) jika mempunyai $F L_{i}$ dan $B L_{i}$ lebih dari satu (Guo dan Hewings, 2001). Angka pengganda output sektor $\mathrm{j}$ didefinisikan sebagai nilai total output yang dihasilkan oleh perekonomian akibat perubahan satu unit permintaan akhir sektor j tersebut (Nazara, 2005: 44) yaitu $O_{j}=$ $\sum_{i=1}^{n} b_{i j}$

Perubahan struktur ekonomi dengan tabel input-output dilihat dengan menggunakan Multiplier Product Matrix (MPM) yang divisualisasikan secara grafis menjadi "Economic landscape". Tinggi grafik batang menunjukkan seberapa besar saling ketergantungan antarsektor dalam perekonomian. Mulitplier Product Matrix (MPM) didefinisikan sebagai $M=\frac{1}{V}\left[\begin{array}{c}B_{1} \\ B_{2 .} \\ \vdots \\ B_{n .}\end{array}\right]\left[\begin{array}{llll}B_{.1} & B_{.2} & \ldots & B_{. j}\end{array}\right]=\left[m_{i j}\right]$. Secara statistik, perubahan struktur ekonomi antar tahun tersebut dapat diketahui dengan 
menghitung korelasi spearman rank terhadap nilai MPM antar waktu (Ramos et al., 2010)

Metode dekomposisi sumber pertumbuhan output ini dikembangkan oleh Chenery (1960) sebagaimana digunakan Mohammadi \& Bazzazan (2000: 5-8) dan Thaiprasert dan Hicks (2011: 58-59). Pertumbuhan output didekomposisikan menjadi perubahan permintaan domestik, perubahan koefisien inputoutput yang ditunjukkan oleh perubahan permintaan antara, perluasan ekspor, subtitusi impor. Proses dekomposisi berawal dari keseimbangan antara penawaran dan permintaan yaitu:

$$
X=D+W+E-M
$$

di mana $\mathrm{X}$ adalah vektor gross output, $\mathrm{D}$ adalah permintaan domestik, W adalah permintaan antara, $\mathrm{E}$ adalah permintaan ekspor dan $\mathrm{M}$ adalah permintaan impor. Jika $W=A X$ di mana $\mathrm{A}=$ matriks koefisien input output $I$ dan $M=m(W+D)$ atau $M=$ $m(A X+D)$ dimana $m_{i}=\frac{M_{i}}{D_{i}+W_{i}}, m=$ matriks diagonal rasio impor maka keseimbangan permintaan dan penawaran dapat dituliskan kembali menjadi:

$X=D+A X+E-m(D+A X)$ atau $X=R(\mu D+E)$

di $\operatorname{mana} \mu=I-m$ dan $R=(I-\mu A)^{-1}$

Perubahan output atau peningkatan output dapat diekspresikan sebagai: $\Delta X=$ $X_{t}-X_{0} \quad$ sehingga $\quad \Delta X=R_{t}\left(\mu_{t} D_{t}+E_{t}\right)-X_{0}$ atau $\quad \Delta X=R_{t} \mu_{t} \Delta \mathrm{D}+R_{t} \Delta E+$ $R_{t} \mu_{t} D_{0}+R_{t} E_{0}-X_{0}$. Dengan manipulasi aljabar dihasilkan bahwa $R_{t} \mu_{t} D_{0}+R_{t} E_{0}-$ $X_{0}=R_{t} \mu_{t} \Delta A X_{0}+R_{t} \Delta \mu\left(A_{0} X_{0}+D_{0}\right) \quad$ sehingga $\quad \Delta X=R_{t} \mu_{t} \Delta \mathrm{D}+R_{t} \Delta E+$ $R_{t} \mu_{t} \Delta A X_{0}+R_{t} \Delta \mu\left(A_{0} X_{0}+D_{0}\right)$. Persamaan tersebut analog dengan Indeks Paasche dan jika dianalogikan dengan Indeks laspayers maka menjadi $\Delta X=R_{0} \mu_{0} \Delta \mathrm{D}+$ $R_{0} \Delta E+R_{0} \mu_{0} \Delta A X_{t}+R_{0} \Delta \mu\left(A_{t} X_{t}+D_{t}\right)$, dimana $R_{t} \mu_{t} \Delta \mathrm{D}$ merupakan dampak perubahan permintaan domestik, $R_{t} \Delta E$ merupakan dampak perubahaan permintaan ekspor, $R_{t} \mu_{t} \Delta A X_{0}$ merupakan dampak perubahan permintaan antara, dan $R_{t} \Delta \mu\left(A_{0} X_{0}+D_{0}\right)$ merupakan dampak perubahan subtitusi impor. Berdasarkan proporsinya, perubahan permintaan domestik dapat dipilah menjadi perubahan konsumsi rumah tangga, perubahan konsumsi pemerintah, pembentukan modal tetap, dan perubahan stok.

Dari sisi penawaran, pertumbuhan output didekomposisi menjadi pertumbuhan produktifitas input antara, pertumbuhan produktifitas tenaga kerja, pertumbuhan produktifitas kapital dan residunya menunjukkan pertumbuhan TFP dengan menggunakan metoda Kuroda dan Namura (2004) sebagaimana diacu oleh Bazazzan (2005) dan Sanjib \& Bahrun (2011). Asumsi dasar yang digunakan adalah (i) pasar tenaga kerja dan pasar modal merupakan pasar persaingan sempurna (perfect competition market), sehingga harga faktor input adalah sesuai dengan produktifitas marginalnya, (ii) Constant Return of Scale sehingga pertumbuhan output sama dengan penjumlahan tertimbang dari pertumbuhan input. Secara matematis dituliskan sebagai $X_{j, t}=\sum_{i=1}^{n} X_{i j, t}+L_{j, t}+K_{j, t}$. Jika perubahan output dinotasikan sebagai $\dot{X}_{J}$, maka pertumbuhan output dapat dituliskan dengan $\frac{\dot{X_{J}}}{X_{j, t}}=\frac{\sum_{i} \dot{X}_{l J}}{X_{j, t}}+\frac{\dot{L_{J}}}{X_{j, t}}+\frac{\dot{K_{J}}}{X_{j, t}}$. Pertumbuhan TFP didefinisikan sebagai pertumbuhan output yang tidak disebabkan karena pertumbuhan input sehingga dapat dirumuskan sebagai berikut: $\left(\frac{\dot{T}_{J}}{T_{j}}\right)_{t}=$ 
$\left(\frac{\dot{X}_{J}}{X_{j}}\right)_{t}-\sum_{i=1}^{n} \frac{X_{i j, t}}{X_{j, t}}\left(\frac{\dot{X}_{l j}}{X_{i j}}\right)_{t}-\frac{L_{j, t}}{X_{j, t}}\left(\frac{\dot{L}_{j}}{L_{j}}\right)_{t}-\frac{K_{j, t}}{X_{j, t}}\left(\frac{\dot{K}_{J}}{K_{j}}\right)_{t} \operatorname{dimana}\left(\frac{\dot{T}_{j}}{T_{j}}\right)_{t}=$ pertumbuhan TFP sektor $\mathrm{j}, X_{j}=$ output sektor $\mathrm{j}, \dot{X}_{j}=$ perubahan $X_{j}$ tahun $\mathrm{t}$ dan $\mathrm{t}+1, X_{i j}=$ input antara sektor j dari sektor i, $L_{j}=$ input tenaga kerja pada sektor $\mathrm{j}, K_{j}=$ input modal pada sektor $\mathrm{j}$.

\section{HASIL DAN PEMBAHASAN}

Analisis Sektor Kunci

Sektor kunci adalah sektor yang menjadi penggerak perekonomian karena mampu menginduksi proses produksi sektor yang menyediakan input baginya dan mudah bergerak jika terjadi perubahan permintaan pada sektor yang menggunakan output-nya dalam proses produksi. Hasil identifikasi sektor kunci di Provinsi Kalimantan Selatan sepanjang tahun 2000-2010 adalah sebagai berikut:

Tabel 1. Sektor Kunci Perekonomian Provinsi Kalimantan Selatan Tahun 2000-2010

\begin{tabular}{|c|c|c|}
\hline 2000 & 2005 & 2010 \\
\hline [1] & [2] & [3] \\
\hline Industri kimia & Industri kimia & Industri kimia \\
\hline Industri karet dan plastik & $\begin{array}{l}\text { Industri makanan, minuman } \\
\text { dan tembakau }\end{array}$ & $\begin{array}{l}\text { Industri makanan, } \\
\text { minuman dan tembakau }\end{array}$ \\
\hline $\begin{array}{l}\text { Industri logam, mesin alat } \\
\text { angkutan dan lainnya }\end{array}$ & $\begin{array}{l}\text { Industri kertas, percetakan dan } \\
\text { penerbitan }\end{array}$ & $\begin{array}{l}\text { Industri logam, mesin alat } \\
\text { angkutan dan lainnya }\end{array}$ \\
\hline \multirow[t]{2}{*}{ Pengangkutan } & $\begin{array}{l}\text { Industri logam, mesin alat } \\
\text { angkutan dan lainnya }\end{array}$ & Pengangkutan \\
\hline & Pengangkutan & \\
\hline
\end{tabular}

Sumber: Diolah dari tabel input-output 2000, 2005 dan 2010

Meskipun dalam struktur nilai tambah sektor industri belum dominan, namun sektor industri di Kalimantan Selatan sedang menuju apa yang dimaksudkan dalam Kaldor's growth law dengan "manufacturing is the engine of growth". Kaldor (1967) sebagaimana diacu dalam Felipe (1998:467) mengemukakan bahwa salah satu alasan sektor industri pengolahan memegang peranan penting adalah karena memiliki keterkaitan ke belakang dan keterkaitan ke depan yang lebih besar dibanding sektorsektor lainnya.

\section{Analisis Angka Pengganda Output}

Secara rata-rata sektor industri memiliki angka pengganda output yang tinggi dibanding sektor primer sehingga pengembangan sektor industri akan memberikan efek domino yang lebih besar bagi penciptaan output total. Sebaliknya sektor pertambangan non migas yang merupakan sektor penopang ekonomi utama hanya memiliki angka pengganda output yang rendah. 


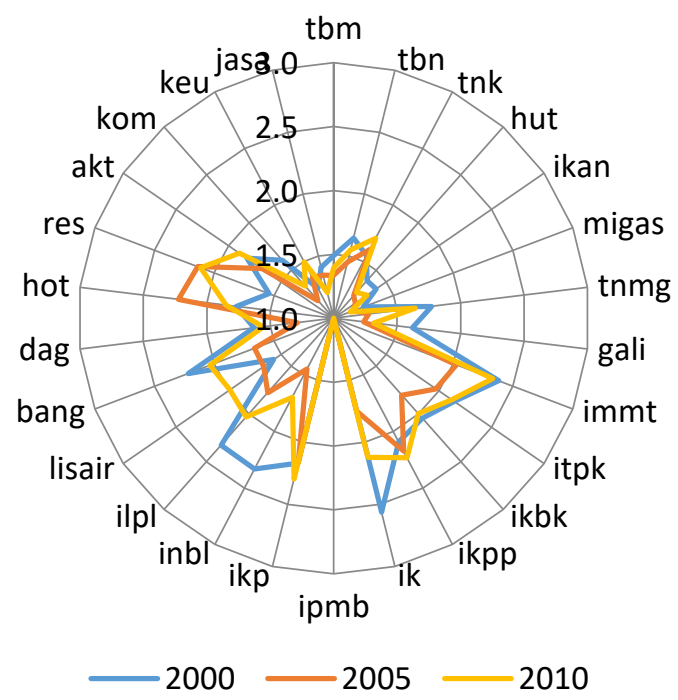

Gambar 1. Angka Pengganda Output 26 Sektor Provinsi Kalimantan Selatan Tahun 2000,2005 dan 2010

Sumber: Diolah dari Tabel Input-Output 2000,2005 2010

Sektor kunci biasanya memiliki angka pengganda output yang juga tinggi. Sektor tersebut mampu menggerakkan perekonomian sekaligus mendorong pertumbuhan ekonomi. Mengacu pada konsep pertumbuhan tidak seimbang oleh Hircshman (1958); Jhinghan (2003), prioritas kebijakan pembangunan harus mulai dialihkan dari sektor pertambangan ke sektor-sektor dalam Tabel 2.

Tabel 2. Sektor Penggerak Utama dan Pendorong Pertumbuhan Ekonomi Provinsi Kalimantan Selatan

\begin{tabular}{|c|c|c|}
\hline 2000 & 2005 & 2010 \\
\hline [1] & [2] & [3] \\
\hline Industri kimia & $\begin{array}{l}\text { Industri makanan, } \\
\text { minuman dan tembakau }\end{array}$ & $\begin{array}{l}\text { Industri makanan, minuman } \\
\text { dan tembakau }\end{array}$ \\
\hline Industri karet dan plastik & $\begin{array}{l}\text { Industri kertas, percetakan } \\
\text { dan penerbitan }\end{array}$ & Industri kimia \\
\hline $\begin{array}{l}\text { Industri logam, mesin alat } \\
\text { angkutan dan lainnya }\end{array}$ & & $\begin{array}{l}\text { Industri logam, mesin alat } \\
\text { angkutan dan lainnya }\end{array}$ \\
\hline
\end{tabular}

Sumber: Diolah dari Tabel Input-Output 2000, 2005, 2010 


\section{Perubahan Struktur Ekonomi Berdasarkan Multiplier Product Matrix (MPM)}

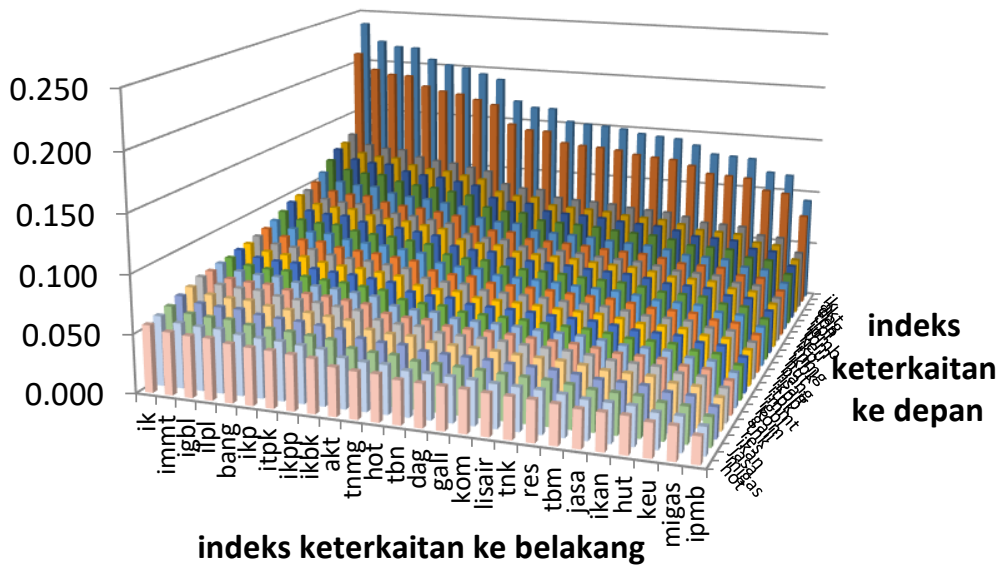

Gambar 2. Economic Landscape Provinsi Kalimantan Selatan, 2000 Sumber: Diolah dari Tabel Input-Output 2000

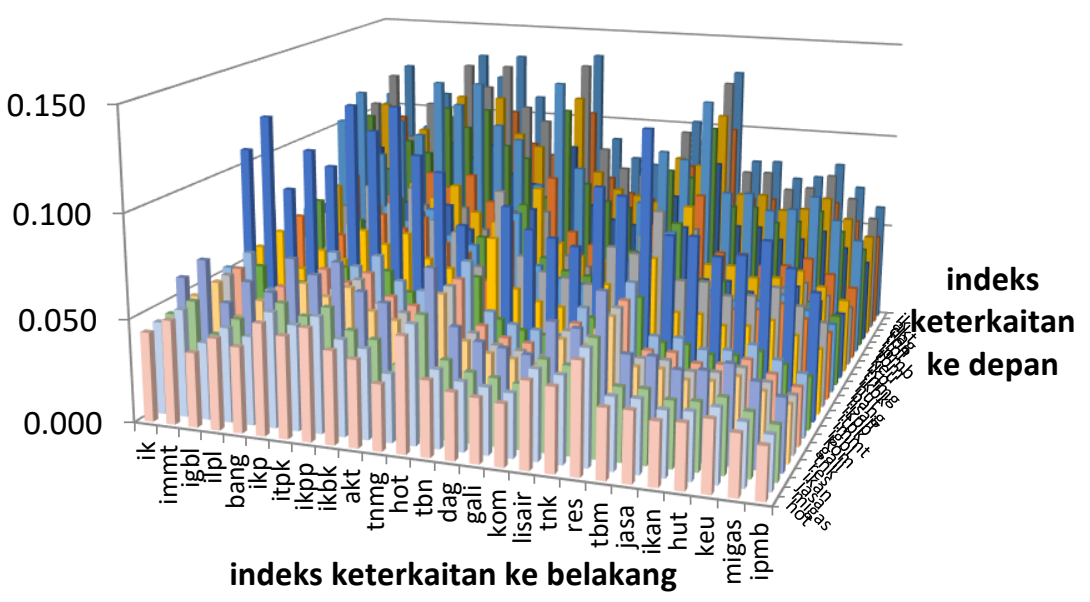

Gambar 3 Economic Landscape Provinsi Kalimantan Selatan, 2005 Sumber: Diolah dari Tabel Input-Output 2005

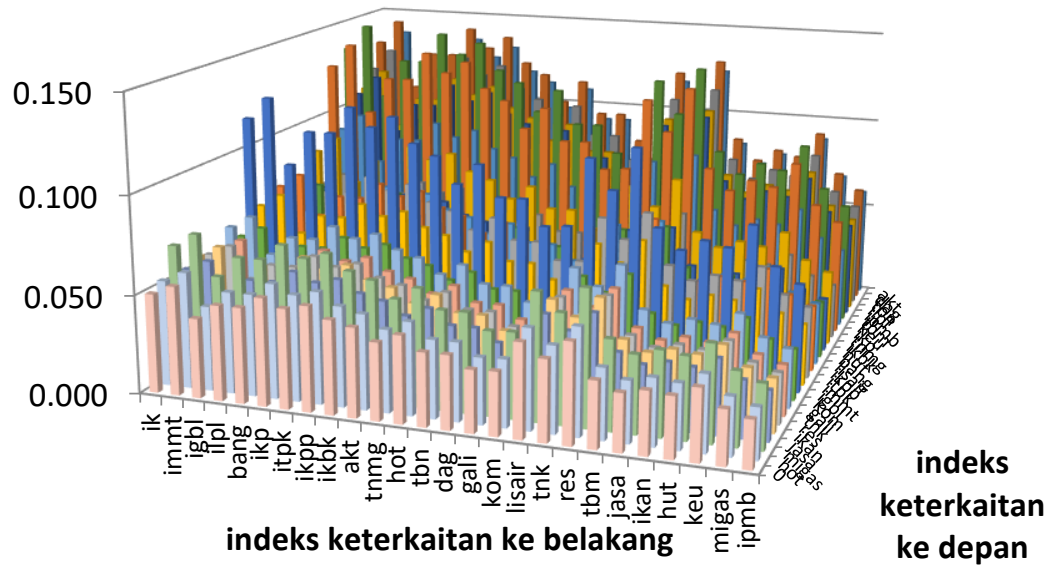

Gambar 4 Economic Landscape Provinsi Kalimantan Selatan, 2010 Sumber: Diolah dari Tabel Input-Output 2010 


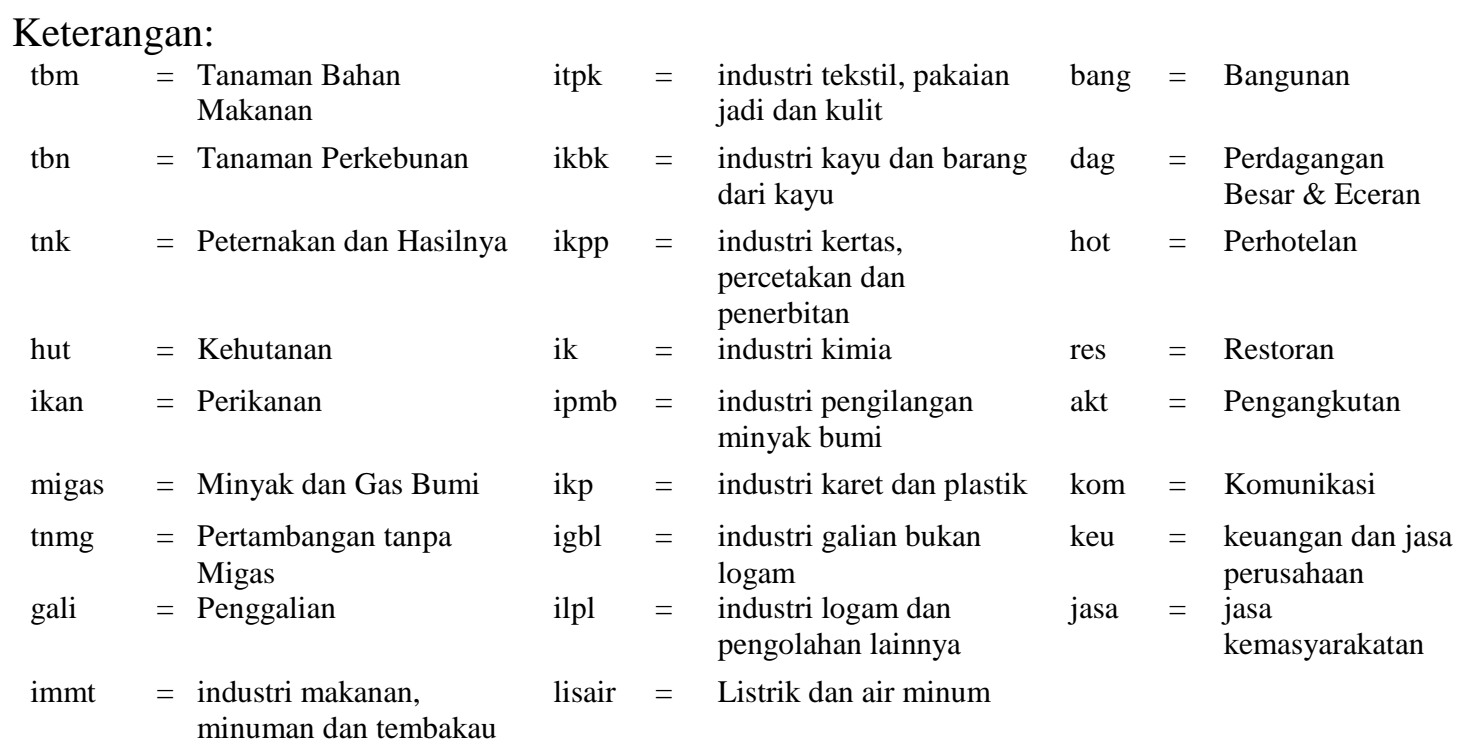

Visualisasi Multiplier Product Matrix (MPM) secara grafis menunjukkan economic landscape pada suatu waktu. Economic landscape pada tahun 2005 berbeda cukup tajam dibandingkan tahun 2000 namun perubahan economic landscape dari tahun 2005-2010 tidak terlalu tajam.Pada tahun 2000, grafik batang tertinggi adalah interaksi antar industri kimia, pada tahun 2005 grafik batang tertinggi menunjukkan interaksi antara sektor industri makanan, minuman dan tembakau dengan sektor perhotelan yang mengalami peningkatan sebesar 159 persen dan pada tahun 2010 interaksi sektor yang paling mempengaruhi perekonomian adalah sektor industri pengilangan minyak bumi dengan sektor industri makanan, minuman dan tembakau dan dengan sektor industri karet dan plastik.

Tabel 3 Uji Korelasi Rank Spearman MPM 2000, 2005, 2010

\begin{tabular}{ccc}
\hline Multiplier Product Matrix & \multicolumn{2}{c}{ Korelasi Rank Spearman } \\
\cline { 2 - 3 } & Koefisien & Signifikansi \\
\hline$[1]$ & {$[2]$} & {$[3]$} \\
\hline Tahun 2000-2005 & 0.732 & 0.000 \\
\hline Tahun 2005-2010 & 0.875 & 0.000 \\
\hline
\end{tabular}

Sumber: Diolah dari Tabel Input-Output 2000, 2005, 2010

Secara statistik perubahan economic landscape antar tahun tersebut dapat dilakukan dengan menghitung korelasi rank spearman pada nilai MPM (Ramos, Estrada dan Fellipe, 2010) dan menunjukkan bahwa terjadi perubahan peringkat yang signifikan antara MPM 2000 dan peringkat MPM 2005 maupun antara peringkat MPM 2005 dan peringkat MPM 2010. 


\section{Sumber Pertumbuhan Output}

Secara umum pertumbuhan ekonomi Provinsi Kalimantan Selatan bersifat export driven economy dengan kontribusi sebesar 67 persen pada tahun 2000-2005 dan 73,72 persen pada tahun 2005-2010. Peningkatan ekpsor terutama berasal dari sektor pertambangan non migas dan sektor industri makanan, minuman dan tembakau yaitu sebesar 60 persen pada tahun 2000-2005 dan pada tahun 2005-2010 menjadi 45 persen.

Tabel 4. Sumber Pertumbuhan Output Provinsi Kalimantan Selatan, 2000-2005 (Persentase dari Output Total)

\begin{tabular}{|c|c|c|c|c|c|c|c|c|}
\hline Sektor & $\begin{array}{c}\text { Konsumsi } \\
\text { rumah } \\
\text { tangga }\end{array}$ & $\begin{array}{c}\text { Konsum } \\
\text { si } \\
\text { pemerint } \\
\text { ah }\end{array}$ & $\begin{array}{c}\text { Pemben- } \\
\text { tukan modal } \\
\text { tetap }\end{array}$ & $\begin{array}{l}\text { Perubahan } \\
\text { stock }\end{array}$ & $\begin{array}{l}\text { Pening- } \\
\text { katan } \\
\text { ekspor }\end{array}$ & $\begin{array}{c}\text { Perubahan } \\
\text { permintaan } \\
\text { antara }\end{array}$ & $\begin{array}{l}\text { Subtitusi } \\
\text { impor }\end{array}$ & Total \\
\hline [1] & [2] & [3] & [4] & [5] & [7] & [8] & [9] & {$[10]$} \\
\hline $\begin{array}{l}\text { Tanaman bahan } \\
\text { makanan }\end{array}$ & 2.72 & 0.00 & 0.00 & 2.17 & 3.42 & -1.77 & 4.27 & 10.81 \\
\hline Tanaman perkebunan & 2.64 & 0.00 & -0.08 & -0.71 & 0.42 & -1.43 & 0.29 & 1.14 \\
\hline Peternakan\&hasilnya & 3.08 & 0.00 & 0.15 & -0.50 & -1.12 & -1.06 & 0.52 & 1.08 \\
\hline Kehutanan & -0.76 & 0.00 & 0.00 & 0.30 & -0.97 & -1.65 & 4.17 & 1.10 \\
\hline Perikanan & -0.78 & 0.00 & 0.00 & 0.01 & -0.96 & 0.96 & 0.33 & -0.44 \\
\hline Minyak\& gas bumi & 0.00 & 0.00 & 0.00 & -0.02 & -0.32 & -0.05 & 0.00 & -0.39 \\
\hline Pertambangan nonmigas & 0.00 & 0.00 & 0.00 & -7.08 & 45.53 & 2.89 & -0.19 & 41.15 \\
\hline Penggalian & 0.77 & 0.00 & 0.00 & 0.00 & 0.06 & 0.24 & -0.05 & 1.02 \\
\hline $\begin{array}{l}\text { Industri makanan, } \\
\text { minuman \&tembakau }\end{array}$ & 12.94 & -1.39 & 0.00 & -10.50 & 14.60 & 3.74 & 8.42 & 27.81 \\
\hline $\begin{array}{l}\text { Industri tekstil, } \\
\text { pakaian jadi dan kulit }\end{array}$ & -0.59 & 0.34 & 0.00 & 0.38 & 0.14 & -0.30 & -0.27 & -0.30 \\
\hline $\begin{array}{l}\text { Industri kayu dan } \\
\text { barang dari kayu }\end{array}$ & 0.62 & 0.01 & -0.06 & -3.20 & -8.32 & -2.35 & 0.76 & -12.54 \\
\hline $\begin{array}{l}\text { Industri kertas, } \\
\text { percetakan dan } \\
\text { penerbitan }\end{array}$ & 0.34 & 0.43 & 0.00 & -0.01 & 0.01 & -0.09 & -0.59 & 0.09 \\
\hline $\begin{array}{l}\text { Industri kertas, } \\
\text { percetakan dan } \\
\text { penerbitan }\end{array}$ & 0.34 & 0.43 & 0.00 & -0.01 & 0.01 & -0.09 & -0.59 & 0.09 \\
\hline Sektor & $\begin{array}{c}\text { Konsumsi } \\
\text { rumah } \\
\text { tangga }\end{array}$ & $\begin{array}{l}\text { Konsum } \\
\text { si } \\
\text { pemerint } \\
\text { ah }\end{array}$ & $\begin{array}{c}\text { Pemben- } \\
\text { tukan modal } \\
\text { tetap }\end{array}$ & $\begin{array}{l}\text { Perubahan } \\
\text { stock }\end{array}$ & $\begin{array}{l}\text { Pening- } \\
\text { katan } \\
\text { ekspor }\end{array}$ & $\begin{array}{l}\text { Perubahan } \\
\text { permintaan } \\
\text { antara }\end{array}$ & $\begin{array}{l}\text { Subtitusi } \\
\text { impor }\end{array}$ & Total \\
\hline$[1]$ & [2] & [3] & [4] & [5] & [7] & [8] & [9] & {$[10]$} \\
\hline $\begin{array}{l}\text { Industri pengilangan } \\
\text { minyak bumi }\end{array}$ & 0.00 & 0.00 & 0.00 & 0.00 & 0.00 & 0.00 & 0.00 & 0.00 \\
\hline Industri karet\& plastik & 2.18 & 0.06 & 0.00 & 1.98 & 1.90 & -5.78 & 0.40 & 0.74 \\
\hline $\begin{array}{l}\text { Industri galian bukan } \\
\text { logam }\end{array}$ & 0.18 & 0.00 & 0.00 & -0.01 & 0.04 & -0.22 & 0.37 & 0.36 \\
\hline $\begin{array}{l}\text { Industri logam dan } \\
\text { pengolahan lainnya }\end{array}$ & 0.81 & 0.02 & -0.44 & 0.25 & -1.20 & -0.43 & 0.74 & -0.25 \\
\hline Listrik dan air minum & 2.52 & 1.46 & 0.00 & -3.26 & 0.19 & -0.46 & 0.13 & 0.58 \\
\hline Bangunan & -0.36 & 0.02 & 0.07 & 0.00 & 0.59 & -1.19 & 0.16 & -0.72 \\
\hline $\begin{array}{l}\text { Perdagangan besar \& } \\
\text { eceran }\end{array}$ & -5.67 & 10.17 & -5.90 & 3.31 & 4.24 & 1.36 & 1.08 & 8.60 \\
\hline Perhotelan & 1.66 & 0.12 & 0.00 & 0.00 & 0.03 & -0.12 & 0.01 & 1.71 \\
\hline Restoran & 7.61 & 0.02 & 0.00 & 0.00 & 0.24 & -0.96 & 0.06 & 6.98 \\
\hline Pengangkutan & 17.04 & 4.14 & -0.05 & 0.00 & 6.42 & -23.02 & 0.99 & 5.52 \\
\hline Komunikasi & 1.78 & 0.44 & 0.00 & 0.00 & 0.55 & -0.49 & 0.03 & 2.31 \\
\hline
\end{tabular}




\begin{tabular}{lrrrrrrrr}
\hline \multicolumn{1}{c}{ Sektor } & $\begin{array}{c}\text { Konsumsi Konsum } \\
\text { rumah } \\
\text { tangga }\end{array}$ & $\begin{array}{c}\text { si } \\
\text { pemerint } \\
\text { ah }\end{array}$ & $\begin{array}{c}\text { Pemben- } \\
\text { tukan modal } \\
\text { tetap }\end{array}$ & $\begin{array}{c}\text { Perubahan } \\
\text { stock }\end{array}$ & $\begin{array}{c}\text { Pening- } \\
\text { katan } \\
\text { ekspor }\end{array}$ & $\begin{array}{c}\text { Perubahan } \\
\text { permintaan } \\
\text { antara }\end{array}$ & $\begin{array}{c}\text { Subtitusi } \\
\text { impor }\end{array}$ & Total \\
\hline $\begin{array}{l}\text { keuangan dan jasa } \\
\text { perusahaan }\end{array}$ & 0.39 & 0.41 & 0.00 & 0.00 & 1.26 & -2.77 & 0.19 & -0.51 \\
\hline \begin{tabular}{l} 
Jasa kemasyarakatan \\
\multicolumn{1}{c}{ Total }
\end{tabular} & 0.69 & 1.03 & 0.00 & 0.00 & 0.13 & -0.37 & 0.05 & 1.54 \\
\hline \multicolumn{1}{c}{51.24} & 18.88 & -6.31 & -17.73 & 67.00 & -37.68 & 24.60 & 100.00 \\
\hline
\end{tabular}

Sumber: Diolah dari Tabel Input-Output 2005, 2010

Peningkatan konsumsi rumah tangga merupakan sumber pertumbuhan kedua dalam pertumbuhan output yaitu sebesar 51,24 persen tahun 2000-2005 dengan sektor utamanya adalah sektor angkutan dan pada periode 2005-2010 mencapai 31,30 persen dengan sektor utamanya adalah sektor tanaman perkebunan. Perbandingan sumber pertumbuhan output total antara 2 periode tersebut dapat dilihat pada Gambar 5.

Tabel 5. Sumber Pertumbuhan Output Provinsi Kalimantan Selatan, 2005-2010 (Persentase dari Output Total)

Sektor Konsumsi Konsumsi Pembentukan Peruba- Pening- Perubahan Subtitusi Total rumah pemerin- modal tetap han stock katan permintaan impor tangga tah

\begin{tabular}{|c|c|c|c|c|c|c|c|c|}
\hline & tangga & tah & & & ekspor & antara & & \\
\hline$[1]$ & [2] & [3] & {$[4]$} & [5] & [7] & [8] & [9] & {$[10]$} \\
\hline $\begin{array}{l}\text { Tanaman bahan } \\
\text { makanan }\end{array}$ & 0.79 & 0.00 & 0.00 & 0.61 & 6.09 & -3.68 & -2.91 & 0.91 \\
\hline Tanaman perkebunan & 11.00 & 0.00 & -6.12 & -4.00 & 3.43 & 2.73 & -0.82 & 6.21 \\
\hline Peternakan\&hasilnya & 1.37 & 0.00 & -0.02 & 0.01 & 0.33 & 0.00 & -0.51 & 1.18 \\
\hline Kehutanan & 0.27 & 0.00 & 0.00 & 0.18 & -0.17 & -0.17 & -0.24 & -0.14 \\
\hline Perikanan & 2.84 & 0.00 & 0.00 & 0.00 & 1.03 & -1.30 & -0.24 & 2.33 \\
\hline Minyak\& gas bumi & 0.00 & 0.00 & 0.00 & 0.02 & -0.80 & 0.08 & 0.00 & -0.70 \\
\hline Pertambangan nonmigas & 0.00 & 0.00 & 0.00 & -0.06 & 29.89 & 0.05 & -6.09 & 23.79 \\
\hline Penggalian & 0.51 & 0.00 & 0.00 & 0.00 & 0.22 & -0.30 & -0.04 & 0.39 \\
\hline Sektor & $\begin{array}{c}\text { Konsumsi } \\
\text { rumah } \\
\text { tangga }\end{array}$ & $\begin{array}{c}\text { Konsumsi } \\
\text { pemerin- } \\
\text { tah }\end{array}$ & $\begin{array}{l}\text { Pembentukan } \\
\text { modal tetap }\end{array}$ & $\begin{array}{l}\text { Peruba- } \\
\text { han stock }\end{array}$ & $\begin{array}{l}\text { Pening- } \\
\text { katan } \\
\text { ekspor }\end{array}$ & $\begin{array}{c}\text { Perubahan } \\
\text { perminta-an } \\
\text { antara }\end{array}$ & $\begin{array}{l}\text { Subtitusi } \\
\text { impor }\end{array}$ & Total \\
\hline [1] & [2] & [3] & [4] & [5] & [7] & {$[8]$} & [9] & [10] \\
\hline $\begin{array}{l}\text { Industri makanan, } \\
\text { minuman \&tembakau }\end{array}$ & 4.31 & 0.43 & 0.00 & -0.17 & 15.37 & 3.01 & -4.51 & 18.44 \\
\hline $\begin{array}{l}\text { Industri tekstil, } \\
\text { pakaian jadi dan kulit }\end{array}$ & 0.19 & 0.02 & 0.00 & 0.09 & 0.20 & 0.03 & -0.54 & -0.01 \\
\hline $\begin{array}{l}\text { Industri kayu dan } \\
\text { barang dari kayu }\end{array}$ & 1.43 & 0.00 & 0.04 & 0.01 & -5.33 & -0.40 & -1.02 & -5.26 \\
\hline $\begin{array}{l}\text { Industri kertas, perce- } \\
\text { takan dan penerbitan }\end{array}$ & -0.40 & 0.42 & 0.00 & 0.03 & 0.04 & 0.03 & 0.01 & 0.13 \\
\hline Industri kimia & 0.31 & 0.08 & 0.00 & 0.03 & 0.67 & 0.02 & -2.72 & -1.62 \\
\hline $\begin{array}{l}\text { Industri pengilangan } \\
\text { minyak bumi }\end{array}$ & 0.00 & 0.00 & 0.00 & 0.00 & 0.00 & 0.00 & 0.00 & 0.00 \\
\hline Industri karet\& plastik & -0.38 & 0.03 & 0.00 & 0.93 & 3.85 & 0.34 & -0.27 & 4.51 \\
\hline $\begin{array}{l}\text { Industri galian bukan } \\
\text { logam }\end{array}$ & 0.32 & 0.00 & 0.00 & 0.42 & 2.46 & 0.44 & 0.39 & 4.04 \\
\hline $\begin{array}{l}\text { Industri logam dan } \\
\text { pengolahan lainnya }\end{array}$ & -0.15 & 0.01 & 0.19 & 0.04 & 0.20 & 0.15 & -0.79 & -0.36 \\
\hline Listrik dan air minum & 0.78 & 0.00 & 0.00 & 0.48 & 0.34 & 0.28 & -0.12 & 1.76 \\
\hline Bangunan & -0.02 & 0.02 & 7.80 & 0.00 & 0.88 & 0.55 & -0.20 & 9.02 \\
\hline
\end{tabular}




\begin{tabular}{lrrrrrrrr}
\hline \multicolumn{1}{c}{ Sektor } & $\begin{array}{c}\text { Konsumsi } \\
\text { rumah } \\
\text { tangga }\end{array}$ & $\begin{array}{c}\text { Konsumsi } \\
\text { pemerin- } \\
\text { tah }\end{array}$ & $\begin{array}{c}\text { Pembentukan } \\
\text { modal tetap }\end{array}$ & $\begin{array}{c}\text { Peruba- } \\
\text { han stock }\end{array}$ & $\begin{array}{c}\text { Pening- } \\
\text { katan } \\
\text { ekspor }\end{array}$ & $\begin{array}{c}\text { Perubahan } \\
\text { permintaan } \\
\text { antara }\end{array}$ & $\begin{array}{c}\text { Subtitusi } \\
\text { impor }\end{array}$ & Total \\
\hline $\begin{array}{l}\text { Perdagangan besar \& } \\
\text { eceran }\end{array}$ & 3.37 & 0.34 & 0.49 & 0.29 & 4.79 & -0.01 & -0.81 & 8.46 \\
\hline $\begin{array}{l}\text { Perhotelan } \\
\text { Restoran }\end{array}$ & -0.03 & 0.02 & 0.00 & 0.00 & 0.12 & 0.19 & -0.03 & 0.27 \\
\hline Pengangkutan & 1.33 & 0.10 & 0.00 & 0.00 & 0.29 & 0.24 & -0.10 & 1.84 \\
\hline Komunikasi & 1.23 & 0.89 & 0.41 & 0.26 & 7.17 & 3.88 & -1.03 & 12.81 \\
\hline $\begin{array}{l}\text { keuangan dan jasa } \\
\text { perusahaan }\end{array}$ & 0.58 & 0.16 & 0.00 & 0.00 & 0.50 & 0.61 & -0.53 & 1.32 \\
\hline \begin{tabular}{l} 
Jasa kemasyarakatan \\
\multicolumn{1}{c}{ Total }
\end{tabular} & 0.71 & 0.24 & -0.10 & 0.00 & 1.74 & 3.32 & -0.56 & 5.35 \\
\hline
\end{tabular}

Sumber: Diolah dari Tabel Input-Output 2005, 2010

Pertumbuhan ekspor tidak mengalami peningkatan yang besar sedangkan permintaan antara mengalami peningkatan yang paling besar, sebagaimana terlihat dengan boxplot warna hitam yang paling tinggi. Menurut Todaro dan Smith (2006: 91 dan 121) strategi pertumbuhan yang bertumpu pada ekspor, terutama jika sebagian besar hasilnya dinikmati oleh pihak-pihak asing akan hanya menguntungkan kelompok tertentu, mengacaukan struktur ekonomi domestik dan membawanya ke arah yang salah (karena tidak melayani kebutuhan masyarakat lokal). Ekspor komoditas primer memiliki elastisitas permintaan terhadap harga yang rendah (inelastis). Komoditas primer juga memiliki keterkaitan ke belakang yang rendah sehingga peningkatan ekspor komoditas ini tidak akan memberikan dampak yang luas terhadap sektor lainnya. Hirschman (1958); Jhinghan (2003:195) menjelaskan bahwa industri tahap akhir merupakan industri kantong ekspor yang paling ideal karena memilki kaitan ke belakang yang sangat luas dan mendalam. Mengacu pada hal tersebut maka pergeseran ekspor dari komoditas bahan mentah ke komoditas industri tentu akan menginduksi sektor-sektor lainnya serta memberikan peningkatan nilai tambah bagi perekonomian.

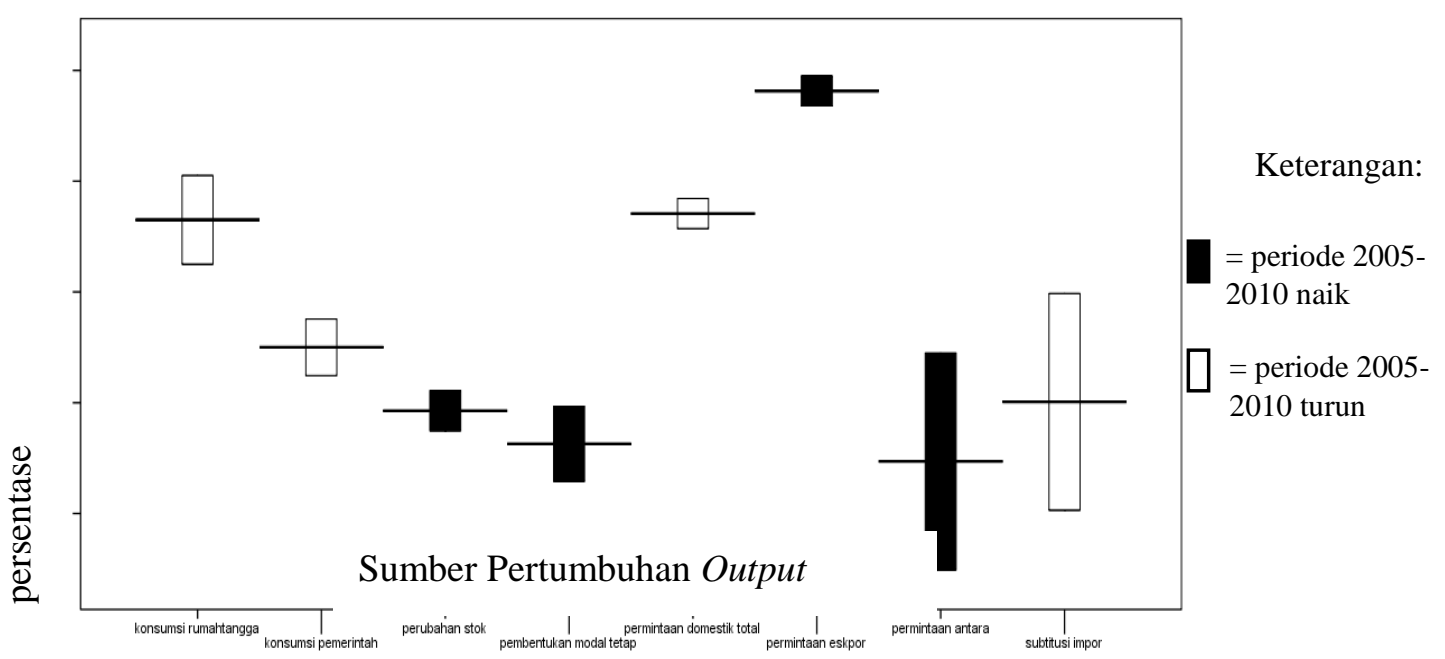

Gambar 5. Sumber Pertumbuhan Output Menurut Permintaan Akhir, 2000-2005 dan 2005-2010 Sumber: Diolah dari Tabel Input-Output 2000, 2005, 2010 


\section{Pertumbuhan Produktifitas Sektoral}

Pada periode 2000-2010 pertumbuhan produktifitas input antara paling tinggi terjadi di sektor industri kimia. Produktifitas tenaga kerja cenderung mengalami penurunan. Hanya ada 3 sektor dengan pertumbuhan produktifitas tenaga kerja tinggi pada tahun 2000-2005 yaitu sektor jasa kemasyarakatan (39,36 persen), sektor industri galian bukan logam (22,89 persen) dan sektor perhotelan (11,63 persen). Sebaliknya produktifitas modal menunjukkan pertumbuhan yang positif di sebagian besar sektor, yaitu sektor perdagangan besar dan eceran (113,41 persen), sektor komunikasi $(113,41$ persen) dan sektor industri galian bukan logam (99,87 persen) pada tahun 2000-2005 sedangkan pada periode 2005-2010 pertumbuhan produktifitas modal yang paling tinggi adalah sektor industri galian bukan logam. Sementara itu dari seluruh sektor hanya sektor industri tekstil, pakaian jadi dan kulit yang memiliki pertumbuhan TFP tidak searah dengan pertumbuhan output-nya

Tabel 6. Pertumbuhan Output dan Produktifitas Input Antara, Tenaga Kerja dan Modal serta TFP, 2000-2005

\begin{tabular}{|c|c|c|c|c|c|}
\hline Sektor & $\begin{array}{l}\text { Pertumbuhan } \\
\text { output }\end{array}$ & $\begin{array}{l}\text { Pertumbuhan } \\
\text { produktifitas } \\
\text { input antara }\end{array}$ & $\begin{array}{l}\text { Pertumbuhan } \\
\text { produktifitas } \\
\text { tenaga kerja }\end{array}$ & $\begin{array}{c}\text { Pertumbuhan } \\
\text { produktifitas } \\
\text { modal }\end{array}$ & $\begin{array}{l}\text { Pertumbuhan } \\
\text { TFP }\end{array}$ \\
\hline [1] & [2] & {$[3]$} & {$[4]$} & {$[5]$} & [6] \\
\hline $\begin{array}{l}\text { Tanaman bahan } \\
\text { makanan }\end{array}$ & 30.99 & 1.72 & 1.29 & 21.75 & 6.23 \\
\hline Tanaman perkebunan & 13.17 & -5.04 & 3.68 & 3.14 & 11.40 \\
\hline Peternakan\&hasilnya & 20.28 & 0.00 & 4.75 & -3.68 & 19.21 \\
\hline Kehutanan & 32.88 & -0.08 & 2.08 & 22.48 & 8.40 \\
\hline Sektor & $\begin{array}{l}\text { Pertumbuhan } \\
\text { output }\end{array}$ & $\begin{array}{l}\text { Pertumbuhan } \\
\text { produktifitas } \\
\text { input antara }\end{array}$ & $\begin{array}{l}\text { Pertumbuhan } \\
\text { produktifitas } \\
\text { tenaga kerja }\end{array}$ & $\begin{array}{c}\text { Pertumbuhan } \\
\text { produktifitas } \\
\text { modal }\end{array}$ & $\begin{array}{l}\text { Pertumbuhan } \\
\text { TFP }\end{array}$ \\
\hline [1] & [2] & [3] & [4] & [5] & [6] \\
\hline Perikanan & -4.49 & 0.00 & 0.91 & -3.65 & -1.75 \\
\hline Minyak \& gas bumi & -5.68 & 0.00 & 0.20 & -5.84 & -0.03 \\
\hline Pertambangan nonmigas & 124.19 & 0.00 & 6.77 & 97.69 & 19.72 \\
\hline Penggalian & 34.89 & 0.00 & 4.08 & 13.94 & 16.87 \\
\hline $\begin{array}{l}\text { Industri makanan, } \\
\text { minuman \&tembakau }\end{array}$ & 69.27 & 0.00 & 1.71 & 23.55 & 44.01 \\
\hline $\begin{array}{l}\text { Industri tekstil, pakaian } \\
\text { jadi dan kulit }\end{array}$ & -17.41 & -3.93 & 0.78 & -15.01 & 0.75 \\
\hline $\begin{array}{l}\text { Industri kayu dan barang } \\
\text { dari kayu }\end{array}$ & -24.80 & -0.37 & -6.49 & 2.65 & -20.60 \\
\hline $\begin{array}{l}\text { Industri kertas, perce- } \\
\text { takan dan penerbitan }\end{array}$ & 11.17 & -1.05 & 0.87 & -15.00 & 26.35 \\
\hline Industri kimia & 39.89 & 19.30 & 4.73 & 37.72 & -21.87 \\
\hline $\begin{array}{l}\text { Industri pengilangan } \\
\text { minyak bumi }\end{array}$ & 0.00 & 0.00 & 0.00 & 0.00 & 0.00 \\
\hline Industri karet \& plastik & 9.82 & -3.57 & -0.20 & -2.90 & 16.49 \\
\hline $\begin{array}{l}\text { Industri galian bukan } \\
\text { logam }\end{array}$ & 119.59 & -0.09 & 22.89 & 99.87 & -3.09 \\
\hline
\end{tabular}




\begin{tabular}{|c|c|c|c|c|c|}
\hline Sektor & $\begin{array}{c}\text { Pertumbuhan } \\
\text { output }\end{array}$ & $\begin{array}{l}\text { Pertumbuhan } \\
\text { produktifitas } \\
\text { input antara }\end{array}$ & $\begin{array}{l}\text { Pertumbuhan } \\
\text { produktifitas } \\
\text { tenaga kerja }\end{array}$ & $\begin{array}{l}\text { Pertumbuhan } \\
\text { produktifitas } \\
\text { modal }\end{array}$ & $\begin{array}{l}\text { Pertumbuhan } \\
\text { TFP }\end{array}$ \\
\hline [1] & [2] & [3] & [4] & [5] & [6] \\
\hline $\begin{array}{l}\text { Industri logam dan } \\
\text { pengolahan lainnya }\end{array}$ & -9.21 & -7.80 & 1.49 & 8.53 & -11.44 \\
\hline Listrik dan air minum & 23.14 & -0.45 & -1.92 & 4.27 & 21.25 \\
\hline Bangunan & -2.76 & 0.99 & 2.84 & 18.70 & -25.29 \\
\hline $\begin{array}{l}\text { Perdagangan besar \& } \\
\text { eceran }\end{array}$ & 25.16 & 1.03 & 3.98 & 20.68 & -0.53 \\
\hline Perhotelan & 597.87 & -0.15 & 11.63 & 131.67 & 454.72 \\
\hline Restoran & 157.52 & 0.00 & 1.80 & 3.82 & 151.90 \\
\hline Pengangkutan & 27.41 & -4.31 & 2.19 & 1.85 & 27.68 \\
\hline Komunikasi & 136.90 & 0.10 & 5.49 & 113.41 & 17.90 \\
\hline $\begin{array}{l}\text { keuangan dan jasa } \\
\text { perusahaan }\end{array}$ & -5.98 & -2.46 & -0.97 & -11.29 & 8.73 \\
\hline Jasa kemasyarakatan & 8.06 & 0.78 & 39.36 & 2.63 & -34.71 \\
\hline \multicolumn{6}{|c|}{ Sumber: Diolah dari Tabel Input-Output 2000, 2005} \\
\hline \multicolumn{6}{|c|}{$\begin{array}{l}\text { Tabel 7. Pertumbuhan Output dan Produktifitas Input Antara, Tenaga Kerja dan Modal serta } \\
\text { TFP, 2005-2010 }\end{array}$} \\
\hline Sektor & $\begin{array}{l}\text { Pertumbuhan } \\
\text { output }\end{array}$ & $\begin{array}{l}\text { Pertumbuhan } \\
\text { produktifitas } \\
\text { input antara }\end{array}$ & $\begin{array}{l}\text { Pertumbuhan } \\
\text { produktifitas } \\
\text { tenaga kerja }\end{array}$ & $\begin{array}{c}\text { Pertumbuhan } \\
\text { produktifitas } \\
\text { modal }\end{array}$ & $\begin{array}{l}\text { Pertumbuhan } \\
\text { TFP }\end{array}$ \\
\hline [1] & [2] & [3] & [4] & [5] & [6] \\
\hline Tanaman bahan makanan & 10.20 & 1.55 & -3.03 & 5.83 & 5.86 \\
\hline Tanaman perkebunan & 187.47 & 0.00 & -5.21 & 81.20 & 111.48 \\
\hline Peternakan\&hasilnya & 92.85 & 0.00 & -5.55 & 40.72 & 57.68 \\
\hline Sektor & $\begin{array}{l}\text { Pertumbuhan } \\
\text { output }\end{array}$ & $\begin{array}{l}\text { Pertumbuhan } \\
\text { produktifitas } \\
\text { input antara }\end{array}$ & $\begin{array}{l}\text { Pertumbuhan } \\
\text { produktifitas } \\
\text { tenaga kerja }\end{array}$ & $\begin{array}{c}\text { Pertumbuhan } \\
\text { produktifitas } \\
\text { modal }\end{array}$ & $\begin{array}{l}\text { Pertumbuhan } \\
\text { TFP }\end{array}$ \\
\hline [1] & [2] & [3] & [4] & [5] & [6] \\
\hline Kehutanan & -16.23 & 0.00 & -3.80 & -10.40 & -2.03 \\
\hline Perikanan & 83.45 & 0.00 & -3.63 & 55.75 & 31.32 \\
\hline Minyak\& gas bumi & -44.95 & 0.00 & -2.22 & -35.38 & -7.35 \\
\hline Pertambangan nonmigas & 126.27 & 0.00 & -4.26 & 45.23 & 85.31 \\
\hline Penggalian & 62.50 & 0.00 & -7.70 & 29.84 & 40.36 \\
\hline $\begin{array}{l}\text { Industri makanan, } \\
\text { minuman \&tembakau }\end{array}$ & 120.61 & 0.00 & -2.19 & 14.45 & 108.35 \\
\hline $\begin{array}{l}\text { Industri tekstil, pakaian } \\
\text { jadi dan kulit }\end{array}$ & -3.97 & -1.31 & -3.79 & -3.08 & 4.21 \\
\hline $\begin{array}{l}\text { Industri kayu dan barang } \\
\text { dari kayu }\end{array}$ & -57.32 & -0.02 & -3.16 & -21.62 & -32.52 \\
\hline $\begin{array}{l}\text { Industri kertas, perce-takan } \\
\text { dan penerbitan }\end{array}$ & 64.07 & -0.33 & -3.10 & 15.74 & 51.76 \\
\hline Industri kimia & -72.64 & 22.34 & -4.16 & -31.55 & -59.28 \\
\hline $\begin{array}{l}\text { Industri pengilangan } \\
\text { minyak bumi }\end{array}$ & 0.00 & 0.00 & 0.00 & 0.00 & 0.00 \\
\hline Industri karet\& plastik & 213.26 & -0.17 & -2.19 & 36.22 & 179.41 \\
\hline
\end{tabular}




\begin{tabular}{|c|c|c|c|c|c|}
\hline Sektor & $\begin{array}{l}\text { Pertumbuhan } \\
\text { output }\end{array}$ & $\begin{array}{c}\text { Pertumbuhan } \\
\text { produktifitas } \\
\text { input antara }\end{array}$ & $\begin{array}{l}\text { Pertumbuhan } \\
\text { produktifitas } \\
\text { tenaga kerja }\end{array}$ & $\begin{array}{c}\text { Pertumbuhan } \\
\text { produktifitas } \\
\text { modal }\end{array}$ & $\begin{array}{c}\text { Pertumbuhan } \\
\text { TFP }\end{array}$ \\
\hline $\begin{array}{l}\text { Industri galian bukan } \\
\text { logam }\end{array}$ & 2560.25 & 0.00 & -4.67 & 1097.16 & 1467.77 \\
\hline $\begin{array}{l}\text { Industri logam dan } \\
\text { pengolahan lainnya }\end{array}$ & -65.14 & -2.77 & -4.22 & -24.53 & -33.62 \\
\hline Listrik dan air minum & 231.64 & 0.00 & -2.87 & 47.41 & 187.10 \\
\hline Bangunan & 157.32 & 0.04 & -7.39 & 23.19 & 141.48 \\
\hline $\begin{array}{l}\text { Perdagangan besar \& } \\
\text { eceran }\end{array}$ & 82.03 & 0.65 & -6.32 & 27.91 & 59.79 \\
\hline Perhotelan & 55.60 & 0.00 & -1.96 & 38.48 & 19.09 \\
\hline Restoran & 66.23 & 0.00 & -2.29 & 22.51 & 46.02 \\
\hline Pengangkutan & 144.35 & -0.57 & -3.71 & 24.54 & 124.09 \\
\hline Komunikasi & 133.20 & 0.00 & -3.92 & 76.10 & 61.02 \\
\hline $\begin{array}{l}\text { keuangan dan jasa } \\
\text { perusahaan }\end{array}$ & 306.67 & 10.38 & -5.56 & 160.45 & 141.39 \\
\hline Jasa kemasyarakatan & 106.76 & 2.12 & -23.07 & 13.58 & 114.14 \\
\hline
\end{tabular}

Sumber: Diolah dari Tabel Input-Output 2005, 2010

Gambar 6 menunjukkan besaran kontribusi masing-masing pertumbuhan produktifitas terhadap pertumbuhan ekonomi selama 2 periode. Pada periode tahun 2000-2005 terlihat bahwa kontribusi terbesar terhadap pertumbuhan ekonomi Provinsi Kalimantan Selatan adalah pertumbuhan TFP (66,42 persen), diikuti kontribusi pertumbuhan produktifitas tenaga kerja (20,97 persen). Pada tahun 2005-2010, pertumbuhan TFP tetap memberikan kontribusi paling besar terhadap pertumbuhan outputmeskipun sedikit menurun yaitu 56,22 persen. Penurunan kontribusi pertumbuhan TFP ini diiringi pertumbuhan produktifitas modal yang mengalami peningkatan kontribusi hingga mencapai 41,67 persen. Selain itu peran pertumbuhan produktifitas tenaga kerja juga mengalami penurunan yang cukup tajam yaitu dari 20,97 persen pada periode 2000-2005 menjadi 1,03 persen pada periode 2005-2010.

\section{Tahun 2000-2005}

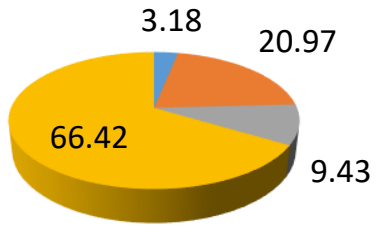

- pertumbuhan produktifitas input antara

- pertumbuhan produktifitas tenaga kerja

pertumbuhan produktifitas modal

pertumbuhan TFP

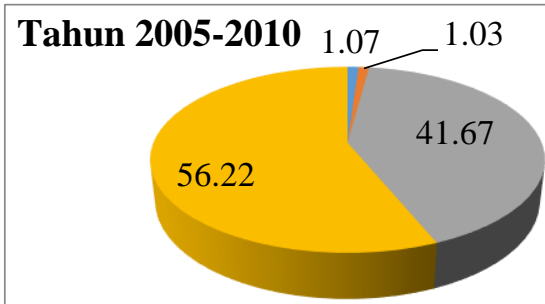

- pertumbuhan produktifitas input antara

- pertumbuhan produktifitas tenaga kerja

- pertumbuhan produktifitas modal

pertumbuhan TFP

Gambar 6. Kontribusi Pertumbuhan Input antara, Tenaga Kerja, Modal dan TFP terhadap Pertumbuhan Output di Provinsi Kalimantan Selatan, 2000-2010 Sumber : diolah dari Tabel Input-Output 2000, 2005, 2010 
Tabel 8. Korelasi Pearson Antara Pertumbuhan Output Dengan Pertumbuhan Produktifitas

\begin{tabular}{|c|c|c|c|c|c|}
\hline \multicolumn{2}{|c|}{ Korelasi Pearson } & $\begin{array}{l}\text { Pertumbuhan } \\
\text { produktifitas } \\
\text { input antara }\end{array}$ & $\begin{array}{c}\text { Pertumbuhan } \\
\text { produktifitas } \\
\text { tenaga kerja }\end{array}$ & $\begin{array}{c}\text { Pertumbuhan } \\
\text { produktifitas } \\
\text { modal }\end{array}$ & $\begin{array}{c}\text { Pertumbuhan } \\
\text { TFP }\end{array}$ \\
\hline \multicolumn{2}{|c|}{$[1]$} & [2] & [3] & [4] & [5] \\
\hline \multirow{4}{*}{$\begin{array}{l}\text { Pertumbuhan } \\
\text { output }\end{array}$} & \multirow[t]{2}{*}{$2000-2005$} & 0.071 & 0.248 & 0.754 & 0.941 \\
\hline & & $(0.731)$ & $(0.221)$ & $(0.000)$ & 0.000 \\
\hline & \multirow[t]{2}{*}{$2005-2010$} & -0.061 & -0.032 & 0.995 & 0.996 \\
\hline & & $(0.767)$ & $(0.875)$ & $(0.000)$ & $(0.000)$ \\
\hline
\end{tabular}

Ket : angka dalam ( ) menunjukkan signifikansi

Sumber: Diolah dari Tabel Input-Output 2000, 2005, 2010

Secara statistik hubungan antara pertumbuhan produktifitas dengan pertumbuhan output dapat dihitung dengan korelasi pearson. Pertumbuhan produktifitas modal dan pertumbuhan TFP memiliki hubungan yang kuat dan searah dengan pertumbuhan output, sedangkan pertumbuhan produktifitas tenaga kerja justru tidak. Dengan demikian peningkatan teknologi dan investasi penting dalam mencapai pertumbuhan ekonomi yang tinggi. Hukum Kaldor-Verdoor sebagaimana diacu Felipe (1998) yang menyatakan bahwa pertumbuhan produktifitas pekerja berhubungan linear dengan pertumbuhan output belum terjadi di Kalimantan Selatan karena tenaga kerja masih terkosentrasi pada sektor pertanian.

\section{Strategi Industrialisasi}

Sebagai daerah yang kaya dengan sumber daya alam, Provinsi Kalimantan Selatan menghadapi tantangan besar dalam perekonomian jangka panjang. Tantangan tersebut adalah bagaimana mengoptimalkan kekayaan yang dimiliki untuk meningkatkan pertumbuhan ekonomi sekaligus mengurangi ketergantungan terhadap sumber daya alam untuk mencapai pembangunan yang berkelanjutan (sustainability development). Tantangan tersebut merupakan upaya untuk menghindari apa yang disebut dengan "resource curse" atau "paradox of plenty".

Industri berbasis sumber daya alam (resources based industries) merupakan strategi untuk menjawab kedua tantangan tersebut. Industrialisasi akan mendorong terjadinya perubahan struktur ekonomi sebagai syarat untuk mencapai pembangunan yang berkelanjutan. Industri yang merupakan penggerak utama dan pendorong pertumbuhan ekonomi berdasarkan analisis diatas sebagaimana tercantum dalam tabel 9.

Tabel 9 Industri Penggerak Utama dan Pendorong Pertumbuhan Ekonomi Menurut Sumber Pertumbuhan Output dan Sumber Produktifitasnya, 2000-2010

\begin{tabular}{ccccc}
\hline \multirow{2}{*}{ Industri } & \multicolumn{2}{c}{ Sumber Pertumbuhan Output } & \multicolumn{2}{c}{ Sumber Produktifitas } \\
& \multicolumn{2}{c}{ Utama } & \multicolumn{2}{c}{ Utama } \\
& $2000-2005$ & $2005-2010$ & $2000-2005$ & $2005-2010$ \\
{$[1]$} & {$[2]$} & {$[3]$} & {$[4]$} & {$[5]$} \\
\hline \multirow{2}{*}{ Industri kimia } & permintaan & subtitusi & modal & TFP \\
& domestik & impor & & \\
\hline
\end{tabular}




\begin{tabular}{|c|c|c|c|c|}
\hline \multirow[t]{2}{*}{ Industri } & \multicolumn{2}{|c|}{$\begin{array}{l}\text { Sumber Pertumbuhan Output } \\
\text { Utama }\end{array}$} & \multicolumn{2}{|c|}{$\begin{array}{c}\text { Sumber Produktifitas } \\
\text { Utama }\end{array}$} \\
\hline & $2000-2005$ & $2005-2010$ & $2000-2005$ & 2005-2010 \\
\hline [1] & [2] & [3] & [4] & {$[5]$} \\
\hline $\begin{array}{l}\text { Industri makanan, minuman } \\
\text { dan tembakau }\end{array}$ & ekspor & ekspor & TFP & TFP \\
\hline Industri karet dan plastik & $\begin{array}{l}\text { permintaan } \\
\text { domestik }\end{array}$ & ekspor & TFP & TFP \\
\hline $\begin{array}{l}\text { Industri kertas, percetakan } \\
\text { dan penerbitan }\end{array}$ & $\begin{array}{c}\text { permintaan } \\
\text { domestik }\end{array}$ & $\begin{array}{l}\text { permintaan } \\
\text { domestik }\end{array}$ & TFP & TFP \\
\hline $\begin{array}{l}\text { Industri logam, mesin, alat } \\
\text { angkutan da industri } \\
\text { pengolahan lainnya }\end{array}$ & ekspor & $\begin{array}{l}\text { subtitusi } \\
\text { impor }\end{array}$ & modal & TFP \\
\hline
\end{tabular}

Sumber: Diolah dari Tabel Input-Output 2000, 2005, 2010

Sektor-sektor dalam Tabel 9 di atas memiliki keterkaitan ke belakang yang tinggi. Tingginya keterkaitan ke belakang sektor industri tersebut ternyata tidak sejalan dengan keterkaitan ke depan sektor pertanian dan pertambangan yang merupakan penyedia input utama bagi industri tersebut. Hanya sektor pertanian bahan makanan dan sektor perkebunan yang memiliki keterkaitan ke depan tinggi. Menurut Kurniawan (2010) ini mengindikasikan tidak adanya link and match antara industri yang dibangun dengan sumber bahan baku yang tersedia. Kebijakan industrialisasi sebaiknya mempertimbangkan link and match antara industri yang dibangun dengan sumber bahan baku yang tersedia.

Tabel 10. Kesesuaian Hasil Analisis Input-Output dengan Klaster Industri Prioritas Kebijakan Industri Nasional Analisis Tabel Input-Output $\quad$ Klaster industri dalam kebijakan industri nasional

\begin{tabular}{ll}
\hline \multicolumn{1}{c}{$[1]$} & \multicolumn{1}{c}{$[2]$} \\
\hline Industri Kimia & Industri petrokimia \\
\cline { 2 - 2 } & Industri semen \\
\hline Industri makanan, minuman dan tembakau & Industri pengolahan kelapa sawit \\
\cline { 2 - 2 } & Industri pengolahan ikan \\
\hline Industri karet dan plastik & Industri karet dan barang dari karet \\
\hline Industri kertas, percetakan dan penerbitan & Industri kertas \\
\hline Industri logam, mesin, alat angkutan dan & Industri baja \\
industri pengolahan lainnya & \\
\hline Sumber: Tabel &
\end{tabular}

Sumber: Tabel Input-Output dan Kemenperindag

Industri berbasis pertambangan dan penggalian yang menjadi prioritas adalah industri baja/bijih besi, industri petrokimia dan industri semen. Keberadaan industri bijih besi ini sangat diperlukan terutama sebagai input bagi industri strategis PT. 
Krakatau Steel. Industri berbasis bahan galian lain yang potensial dikembangkan adalah industri semen. Hingga saat ini baru terdapat satu industri semen dan baru memanfaatkan sebagian kecil bahan baku yang ada sehingga sangat perlu dorongan investasi bagi industri semen baru. Ketiga industri tersebut merupakan industri yang bersifat padat modal (capital intensive), padat teknologi (technology intensive) dan lahap energi (high absorbed energy). Dengan dukungan batubara sebagai sumber energi, dorongan investasi dalam industri tersebut akan menimbulkan efek berantai pada sektor lain serta mendorong pertumbuhan ekonomi dengan tetap mengedepankan prinsip good mining practice. Pengembangan industri ini mutlak memerlukan integrasi antara pihak swasta dan pemerintah daerah maupun pemerintah pusat serta memerlukan rangkaian kebijakan dan strategi yang berkesinambungan.

\section{KESIMPULAN}

Dari hasil analisis di atas dapat diambil kesimpulan yaitu: (1) Sektor penggerak utama dan pendorong pertumbuhan ekonomi di Provinsi Kalimantan Selatan adalah industri pengolahan yaitu: industri kimia, industri makanan, minuman dan tembakau, industri karet dan plastik, industri kertas, percetakan dan penerbitan serta industri logam, mesin, alat angkutan dan industri pengolahan lainnya, meskipun penopang ekonomi terbesar sebagaimana terlihat dalam pangsa PDRB tetap sektor pertambangan dan penggalian yaitu sebesar 45,87 persen namun sektor ini memiliki indeks keterkaitan dan angka pengganda output yang rendah, (2) Provinsi Kalimantan Selatan sedang menuju perubahan struktur ekonomi dimana sektor industri mulai menunjukkan peran yang dominan dalam perekonomian khususnya industri kimia pada tahun 2000, industri makanan, minuman dan tembakau dan sektor perhotelan pada tahun 2005 dan sektor industri makanan, minuman dan tembakau serta industri pengilangan minyak bumi pada tahun 2010, (3) Sumber pertumbuhan ekonomi utama di Provinsi Kalimantan Selatan adalah ekspor yaitu sebesar 67 persen pada periode 2000-2005 dan 73,72 persen pada periode 2005-2010 terutama ekspor batubara. Pertumbuhan yang bertumpu pada ekspor komoditas primer memiliki elastisitas permintaan terhadap harga yang rendah dan tidak memberikan dampak yang luas terhadap sektor lain, (4) Pertumbuhan TFP dan produktifitas modal mempunyai hubungan linear yang kuat dan searah dengan pertumbuhan output sedangkan produktifitas tenaga kerja dan input antara tidak. Artinya peningkatan teknologi sangat diperlukan agar penggunaan input lebih efisien. Hukum Verdoorn yang menyatakan bahwa pertumbuhan produktifitas tenaga kerja berhubungan linear dengan pertumbuhan output belum terjadi di Kalimantan Selatan, dan (5) Strategi industri yang berorientasi pada peningkatan pertumbuhan ekonomi dan pembangunan berkelanjutan di Provinsi Kalimantan Selatan adalah industri berbasis pertanian dan pertambangan. Strategi ini memerlukanlink and match antara industri yang dibangun dengan sumber bahan baku yang tersedia. Sebagai langkah awal, diperlukan strategi subtitusi impor dan peningkatan investasi dalam bentuk modal dan teknologi.

Provinsi Kalimantan Selatan sudah tidak bisa lagi mengandalkan sektor pertambangan karena bersifat "enclave economy" dan tidak sejalan dengan prinsip pembangunan yang berkelanjutan. Oleh karena itu kebijakan ekonomi harus diprioritaskan pada industri-industri penggerak dan pendorong pertumbuhan ekonomi. 
Industri berbasis sumber daya alam memerlukan strategi hilirisasi terhadap sektorsektor primer. Peningkatan output sektor primer secara absolut tetap menjadi prioritas karena pertumbuhan sektor industri harus didorong oleh pertumbuhan sektor primer. Selanjutnya penulis itu menyarankan penggunaan analisis tabel input-output sebagai dasar penyusunan rencana kebijakan ekonomi daerah maupun nasional.

\section{DAFTAR RUJUKAN}

Bazzazan, F. (2005). Sectoral Productivity Change in Iran.Paper presented at $17^{\text {th }}$ International Input-Output Conference, 13-17 ${ }^{\text {th }}$ July 2005, Sao Paolo, Brazil

Chenery, H. (1979). Industrialization and Growth Alternative Views of East Asia, in Hughes, Helen.Achieving Industrialization in East Asia. 1988. Cambridge University Pres.

Chenery, H., \& Syrquin, M. (1975). Patterns of Development 1950 - 1970. London. Oxford University Press.

Felipe, J. (1998). The Role of The Manufacturing Sector in SouthEast Asian Development: A Test of Kaldor's First Law. Journal of Post Keynesian Economics, 20(3), 463-485.

Guo, D., \& Hewings, G. (2001). Comparative Analysis of China's Economic Structures Between 1987 - 1997. An Input-Ouput Prospective. Discussion Paper in REAL

Guo, D., \& Planting, M.A. (2000). Using Input Output Analysis to Measure U.S Economic Structure Change Over a 24 years period. Paper Presented at the $13^{\text {th }}$ International Conference on Input Output Techniques.

Hayashi, M. (2005). Structural Changes In Indonesian Industry and Trade: An InputOutput Analysis.The Developing Economies, XLIII-1.

Hirschman, A. (1958). The Strategy of Economic Development, New Haven, Yale University.

Jhinghan, M.L. (2003). Ekonomi Pembangunan dan Perencanaan. Jakarta: Raja Grafindo Persada.

Kuncoro, M. (2010). Ekonomi Pembangunan: Masalah, Kebijakan dan Politik.Jakarta: Erlangga.

Kuroda, M., \& Nomura, K. (2004). Technological Change and Accumulated Capital: A Dynamic Decomposition of Japan's Growth", in Dietzenbacher E dan Lahr M (ed). Wassily Leontief and Input-Output Economics, Cambridge University Pres

Lewis, W. A. (1954). Economic Development with Unlimited Supplies of Labour. The Manchester School, 22(2), 139-191.

Mankiw, N. G. (2007). Makroekonomi. Jakarta: Erlangga.

Mohammadi, N., \& Bazzazan, F. (2000). Sources of Economics Growth and Input Output Structural Decomposition Analysis: The Case of Iran.

Nazara, S. (2005). Analisis Input-Output.Jakarta: Lembaga Penerbit Fakultas Ekonomi Universitas Indonesia.

Ramos, N.M., Estrada, G., \& Felipe, J. (2010). Exploring the Philippine Economic Landscape and Structural Change Using The Input Output Framework. International Journal of Development Issues, 10(1), 34-59.

Sabriroglu., Iklin, M., \& Bashirli, S. (2012). Input-Output Analysis in Oil-Rich Economy: The Case of Azerbaijan.Resource Policy, 37, 73-80. 
Sanjib, P., \& Barun, P. (2011). Productivity and Technical Change in Indian Economy.Munich Personal REPEC Archive No 32736.

Thaiprasert, N., \& Hicks, M. (2011). Industrial Growth in Indiana: Demand Side Decomposition, 2001-2006. The Journal of Regional Analysis and Policy, 41(1), 53-69.

Todaro, M.P., \& Smith, S. C. (2006). Pembangunan Ekonomi Jilid 1 dan 2. Jakarta: Erlangga. 